\title{
Submarine Outfalls are an Effective Solution for the Disposal of Properly Treated Sewage of Coastal Cities
}

Eduardo Pacheco Jordão / Paulo Cesar Colonna Rosman

DOI 10.4322/dae.2016.016

\section{ABSTRACT}

Many coastal cities in the world have adopted submarine outfall as the solution for their sewage disposal. Brazil, a country with a coastline of $7,500 \mathrm{~km}$, or quite more if one includes the perimeters of bays, has had a good experience with submarine outfalls for sewage disposal. It has proved to be a safe and economical solution to keep coastal waters to meet quality standards. The paper covers aspects such as bathing standards, legislation, refers to the main outfalls in Brazil, suggested pretreatment, and trends in the outfall design.

Keywords: Submarine outfall, sewage disposal, seawater quality, pretreatment, bacterial decay model.

\section{RESUMO}

Muitas cidades litorâneas no mundo têm adotado emissários submarinos como solução para a destinação final de seus esgotos sanitários. No Brasil, um país com uma linha de costa com mais de $7500 \mathrm{~km}$,ou bem mais incluindo perímetros de baías, esta solução tem-se mostrado segura e econômica para manter a qualidade das águas costeiras de acordo com os padrões de qualidade.

O artigo cobre aspectos como padrões de balneabilidade, legislação, comenta sobre os principais emissários no Brasil, pré-tratamentos recomendados, e tendências em projeto de emissários.

Palavras-chave: Emissário submarino, disposição final de esgotos, qualidade da água do mar, pré-tratamento, modelo de decaimento bacteriológico.

\section{INTRODUCTION}

Brazil is the largest country in South America, with a coastline of $7,500 \mathrm{~km}$, or quite more if one includes the perimeters of bays. It's beautiful beaches are famous, such as Copacabana and Ipanema in Rio de Janeiro, as seen in Figure 1.

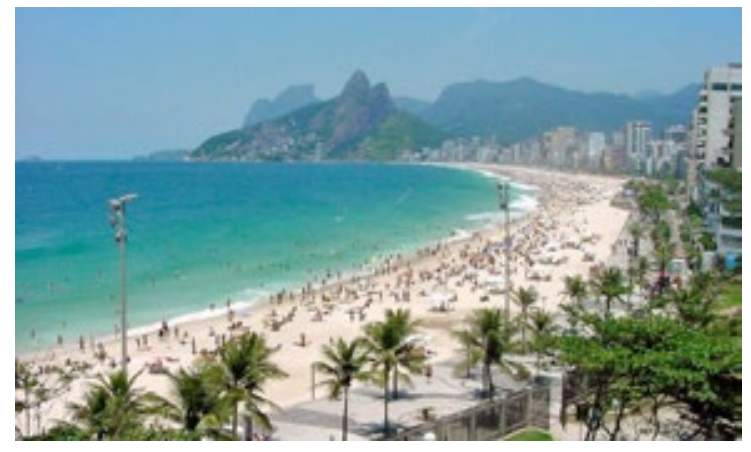

Figure 1: Ipanema Beach, in Rio

Eduardo Pacheco Jordão, Dr. Eng., jordaoapoli.ufrj.br Paulo Cesar Colonna Rosman, Ph.D., pccrosmanapoli.ufrj.br Engineers and Professors

Escola Politécnica, Universidade Federal do Rio de Janeiro. 
Having such a long coast, sewage disposal through submarine outfalls comes to be an economical and safe solution. Yet, proper legislation must control projects that adopt such a type of solution.

\section{LEGISLATION}

Brazil's Federal Resolution 357/2005 presents different "classes of water", including saline water, and the Resolution 430/2011 establishes specific conditions for sewage discharge into the ocean. CONAMA, the Brazilian Council for the Environment, issued both. Back in the year 2000, the same federal agency had issued bathing standards for seawater.

Table 1 shows standards for saline water, and Table 2 shows quality criteria required for any discharge from a treatment plant (WWTP). The beneficial uses intended for the water define required quality standards.

States in Brazil may have legislation that is more stringent. For instance, Rio de Janeiro State requires at least a standard primary treatment prior to any sewage outfall, even into the ocean.

Table 1: Bathing standards for saline waters $(*)$.

\begin{tabular}{|c|c|c|c|}
\hline Water Class & $\begin{array}{c}\text { TOC } \\
(\mathbf{m g} / \mathbf{L})\end{array}$ & $\begin{array}{c}\text { DO } \\
(\mathbf{m g} / \mathbf{L})\end{array}$ & $\begin{array}{c}\mathbf{F C} \\
\mathbf{( m p n / 1 0 0 m L )}\end{array}$ \\
\hline 1 & 3 & 6 & 1000 \\
\hline 2 & 5 & 5 & 2500 \\
\hline 3 & 10 & 4 & 4000 \\
\hline
\end{tabular}

(*)CONAMA 357/2005. TOC $=$ Total Organic Carbon; DO = Dissolved Oxygen; FC = Fecal Coliform.

Table 2: Minimum quality for effluent from WWTP (*)

\begin{tabular}{|c|c|}
\hline Parameter & Concentration ( $\leq$ ) \\
\hline $\mathrm{pH}$ & $5-9$ \\
\hline Temperature & $40^{\circ} \mathrm{C}$ \\
\hline Settable Solids & $1 \mathrm{~mL} / \mathrm{L}$ \\
\hline O\&G sol. in hexane & $100 \mathrm{mg} / \mathrm{L}$ \\
\hline Floatable material & Absent \\
\hline BOD & $120 \mathrm{mg} / \mathrm{L}$ \\
\hline
\end{tabular}

(*)CONAMA 430/2011

\section{BRAZILIAN OUTFALLS}

Table 3 shows the main outfalls and their characteristics along the Brazilian coastline.

Table 3: Main outfalls along the Brazilian coast.

\begin{tabular}{|c|c|c|c|c|c|}
\hline City & $\begin{array}{l}\text { Flow } \\
\left(\mathrm{m}^{3} / \mathrm{s}\right)\end{array}$ & $\begin{array}{c}\underset{E}{E} \\
(\mathrm{~m})\end{array}$ & $\begin{array}{l}\text { Length } \\
\text { (m) }\end{array}$ & $\begin{array}{c}\text { Depth } \\
\text { (m) }\end{array}$ & Material \\
\hline Belém & 0.6 & 0.80 & 3,200 & 12 & $C$ \\
\hline Fortaleza & 2.5 & 1.50 & 2,300 & 15 & $P E A D$ \\
\hline Bahia 1 & 8.3 & 1.75 & 2,350 & 27 & $C$ \\
\hline Bahia 2 & 5.9 & 1.60 & 3,670 & 45 & $C$ \\
\hline Vitoria & 2.1 & 1.50 & 4,035 & 29 & -- \\
\hline Niterói & 2.2 & 1.40 & 3,505 & 20 & $P E A D$ \\
\hline Rio (*) & 15.0 & 2.40 & 4,325 & 26 & $C P$ \\
\hline Rio ("***) & 5.3 & 1.50 & 5,000 & --- & PEAD \\
\hline Santos $O$ & 1.0 & 0.86 & 200 & 10 & $S / C$ \\
\hline Santos N & 4.1 & 1.50 & 4,500 & -- & -- \\
\hline P. Alegre & 2.7 & 1.26 & 733 & 12 & $S$ \\
\hline Manaus & 1.0 & 1.00 & 3,600 & 58 & PEAD \\
\hline Maceió & 0.4 & 0.50 & 4,250 & 17 & PFV \\
\hline Aracruz & 3.0 & 1.20 & 2,500 & 17 & $P P$ \\
\hline \multicolumn{6}{|c|}{$\begin{array}{l}\text { Ipanema. }(* *) \text { Barra da Tijuca. Santos } O=\text { old. Santos }(*) N=\text { new. Bahia } 1= \\
\text { Rio Vermelho (Salvador). Bahia } 2=\text { Jaguaribe (Salvador). } \\
C=\text { concrete; } C P=\text { prestressed concrete; } S=\text { steel; } S / C=\text { concrete } \\
\text { (steel covered); } P E A D=\text { high density polyetilene; } P F V=\text { polyester; } P P= \\
\text { polypropylene }\end{array}$} \\
\hline
\end{tabular}

Allegedly, these outfalls operate according to the expected studies and design, providing safe conditions for bathing and recreational activities along the beaches.

However, although the costal currents disperse adequately the plume of the Ipanema outfall, granting that its effluents do not affect the bathing zone along the beaches, its pretreatment facilities are limited to screens.

\section{PRETREATMENT}

Any submarine outfall must be preceded by some minimal pretreatment system, capable to retaining solids above a very small particle size (such as 1.0 $\mathrm{mm}$ ), that otherwise would float in the receiving waters. Usually there are local legislations and norms concerning the minimum level of treatment. 
In the ocean, the sewage plume ejected from the outfall might disperse rapidly. Usually, the near field dilution is in the order of 1:100 to 1:200. Under such dilution rates, the concentrations of BOD and nutrients will meet quality standards at the end of the near field zone. The issue remains in meeting proper bacteriological indices, according toTable 4.

Table 4: Bathing Waters Classification according to Bacteriological Indices (*).

\begin{tabular}{|c|c|c|c|}
\hline Condition & $\mathrm{FC}(\leq)$ & $E C(\leq)$ & $\operatorname{ENCC~(\leq )~}$ \\
\hline Excellent & 250 & 200 & 25 \\
\hline Very Good & 500 & 400 & 50 \\
\hline Satisfactory & 1000 & 800 & 100 \\
\hline Inadequate & $>2500$ & $>2000$ & $>400$ \\
\hline
\end{tabular}

(*)CONAMA-357/2005; Numbers apply to $80 \%$ of the time in samples collected in the previous 5 weeks. $\mathrm{FC}=$ Fecal Coliform; $\mathrm{EC}=$ Escherichia Coli, ENCC $=$ Enterococcus

In the far field, due to further mixing and decay processes, within a few hours concentrations can decrease more than 10,000 times. Thus, for marine disposal of domestic wastewater, it might be irrelevant to adopt secondary or biological treatments prior to the outfall. Moreover, the BOD removal in any pretreatment process will not affect significantly the oxygen content of the seawater.

On the other end, nutrient disposal to the ocean does not create any harmful pollution problem. Ocean currents properly disperse any nutrient load from the wastewater, even if the diffuser line of the outfall has a good design.

Considering these comments, the system should remove two kinds of pollutants, besides coarse debris through screening, and grit at grit chambers:

- Floatable material, which may cause a deleterious appearance; and

- Possible pathogenic bacteria and viruses.
Nowadays the best equipment to remove floatable and small solids particles is a micro-screen, with sifter holes of $0.25 \mathrm{~mm}$, v.Figure 2. Usually sifter holes are from 0.5 to $1.5 \mathrm{~mm}$. See METCALF \& EDDY (2014) and JORDÃO \& PESSÔA (2014).

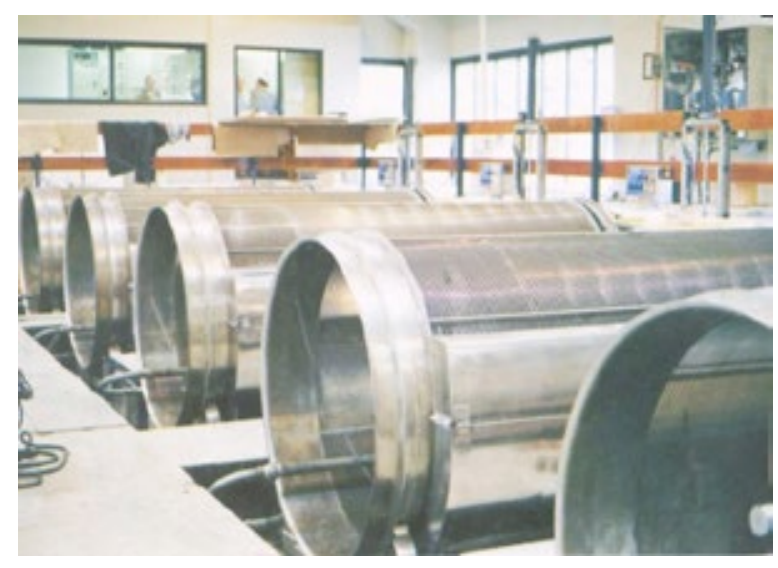

Figure 2: Micro-screens for floatables and small solid particles removal.

\section{PUBLIC HEALTH}

Chlorination, and/or inactivation at the seawater, can greatly reduce bacteria and viruses concentrations. Salinity, but mostly the ultraviolet radiation of sunlight, is effective inactivation agents.

In Brazil, the CONAMA-357/2005 resolution classifies bathing waters according to Table 4.Usually proper dilution and ambient inactivation suffices to meet the standards, without the need of chlorination. However, if a shorten length of the outfall is desired, disinfection may be required.

Any outfall disposal study should take into account the costs and risks associated with chlorine disinfection. Besides the usually high costs, there are hazards in transporting large quantities of chlorine to the outfall site. Chlorine may pose risks to the plant personnel, and cause toxicity in the aquatic environment. 


\section{MODERN TRENDS}

There are public opinion issues concerning the use of submarine sewage outfalls, but most are misconceptions. The common idea that sewage outfall plumes pollute bathing zones along nearby beaches, and cause eutrophication in coastal waters, is often a fallacy that does not stand quantified analyses.

Computer models can simulate quite accurately the complex behavior of outfall plumes in the marine environment, including realistic variable bacterial decay processes, FEITOSA R.C. \& ROSMAN P.C.C. (2007). From the near field, where initial dilution and active mixing of the ejected plume from the diffuser line occur, to the vanishing passive plume in the fringes of the far field stretch.

In confronting field data with model results, following proper calibration and validation procedures, one can be confident in such quantified analyses. See, e.g., section 9 in ROSMAN P.C.C. (Ed.) (2016). Therefore, one must confront misconceptions with real values, and assess the actual impact of the outfall plume in the environment.

Modern computer models are capable to simulate, with adequate accuracy, at least the following coupled phenomena: near field active mixing, that forms the waste field to be passively transported in the far field, by advective-diffusive processes, and variable bacterial decay kinetics, as a function of water salinity and temperature, and incidence of solar radiation.

\section{COUPLED NEAR AND FAR FIELDS}

Within the near field of the diffuser line, the main process is the active mixing due to momentum gradients between the ejected effluent and the receiving waters. Referring to Figure 3 , momentum gradients derive from differences in densities and velocities of the effluent $\left(\rho_{0} U_{0}\right)$ and the receiving waters $\left(\rho_{z} U_{z}\right)$. At the end of the near field length, among other variables, models must compute the minimum dilution rate $\left(\mathrm{C}_{\max } / \mathrm{C}_{0}\right)$, the thickness of the formed passive waste field $(\mathrm{H})$, and the distance from the bottom to the top of the passive plume $\left(\mathrm{Z}_{\text {top }}\right) \cdot \mathrm{C}_{\max }$ and $\mathrm{C}_{\mathrm{o}}$ are concentrations.

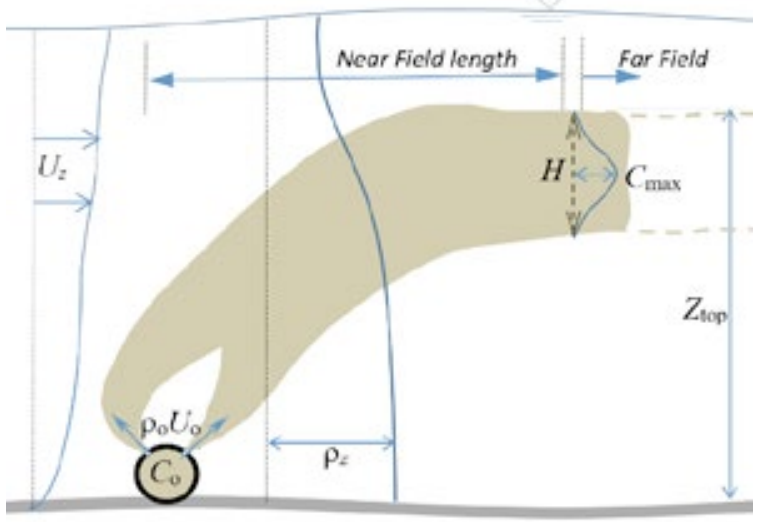

Figure 3: Main variables pertinent to the near field of the plume ejected from the diffusers of the outfall.

Considering momentum conservation principle, as the effluent buoyant jet rises from the diffusers, entrainment with the receiving waters increases the jet mass and density, and decreases its velocity in similar proportion. This occurs along the near field length, up to a distance where momentum inside and outside of the developing plume nearly equalize. Thereon, the plume is passively transported by ambient currents, and the far field processes begin. There are many seminal papers in this respect published by Philip J. W. Roberts and coauthors, starting in ROBERTS, P.J.W. (1979). FEITOSA R.C. (2007) refers to an extensive list of such papers.

In twenty minutes or so, the ejected effluent reaches the end of the near field. For that, it is irrelevant to consider decay processes in this active mixing zone. But those are very important in the passive mixing zone of the far field.

In the far field, there are no momentum differences between the receiving waters and the plume. Therefore, its hydrodynamic influence in the am- 
bient flow is practically nil, the plume is transported passively, affecting only the water quality within its bounds. Any model must account for three main processes in the far field: advection, turbulent diffusion and kinetic reactions.

Advection comprises the advective transport caused by the prevailing currents. The ambient turbulence passively mixes the plume within itself and with surrounding waters. This turbulent diffusion processes continue to dilute the plume, but in a much lower rate than the one in the active mixing zone within the near field.

Advection and turbulent diffusion are intertwined processes that depend heavily on the refinement of the computer model spatial discretization. Turbulent diffusion is the way to account for the flow minutia that cannot be directly resolved with the adopted spatial discretization. For instance, consider modeling the same flow field with two spatial grids. The first quite fine and the second coarser. In the first case, the model can resolve more varied nuances and details of the flow field, and a richer advection results. In this case, there is less unresolved flow field details to be modeled as turbulent diffusion. In the second case, the opposite occurs. In the unreachable theoretical limit, a model in minute direct simulation scales would compute all microscopic details of the flow field, turbulence would vanish, remaining only advection and molecular diffusion.

Direct simulation scales are unviable for modeling geophysical flows, considering costs and consistent data to feed the model. In response, a usual viable approach is to model the flow field in a conventional eulerian coarse mesh, and adopt a lagrangian approach to model the transport of the plume. With this method, concentrations are computed in cells of an adaptive refined computational mesh that dynamically surrounds the transported plume. Thence, advection and turbulent diffusion processes are properly represented cf. Figure 4.
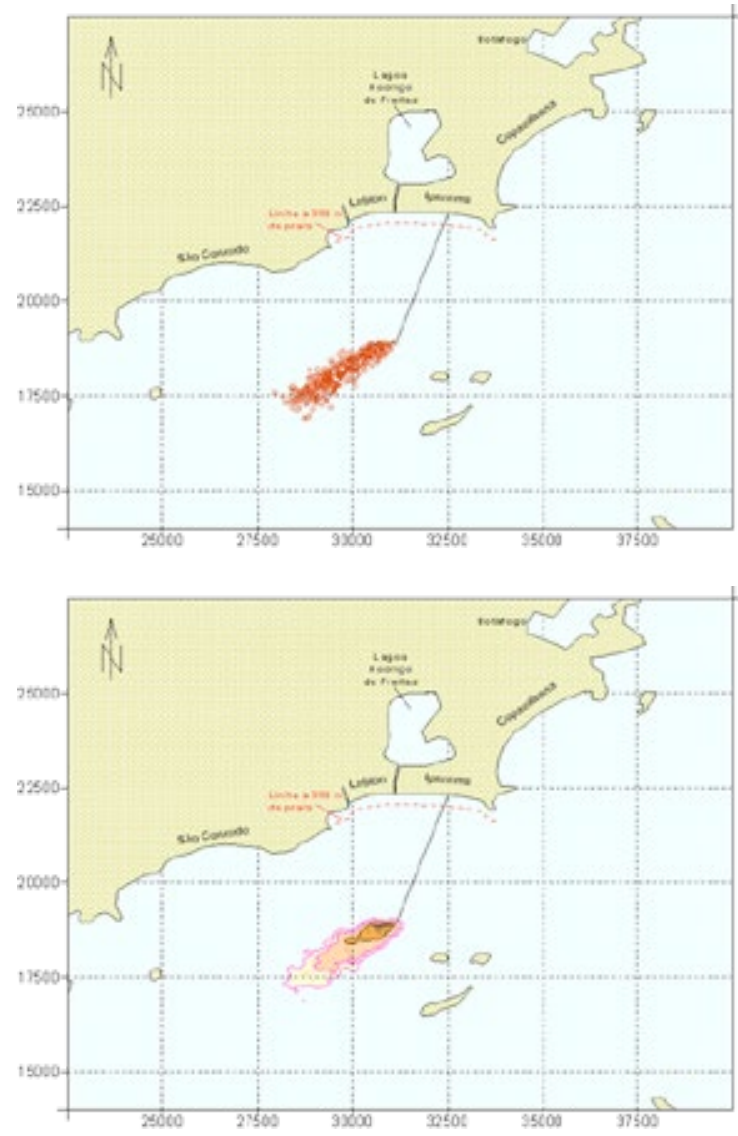

Figure 4: Top map shows the advective and dispersive turbulent transport of particles in a lagrangian model of the Ipanema outfall plume in the far field. The bottom map depicts concentration isolines computed via an adaptive mesh that surrounds the moving plume of particles, ROSMAN P.C.C. (Ed.) (2016).

Academic research on the methodology of integrating near and far field phenomena to model outfall plumes is going on for more than twenty years. Some early examples are in the works of SANTOS (1995), HORITA (1997), AND ZHANG \& ADAMS (1999). EXAMPLES OFMORE RECENT, AND REALISTIC APPROACHES ARE IN THE WORKS OF BLENINGER (2006) AND FEITOSA (2007).

\section{COUPLED VARIABLE BACTERIAL DECAY MODEL}

Bathing conditions, cf. Table 4 , is perhaps the main issues regarding public opinion misconceptions towards sewage outfalls. Quite often, media 
articles blame outfalls for improper bathing waters along beaches in the vicinity.

Considering that the near and far field advective diffusive transport of plumes are well represented by modern computer models, the coupling of a realistic bacterial decay kinematics in the processes is of utmost importance.

Unfortunately, some studies continue to apply simplistic first order reactions to compute bacterial decay. Such models usually adopt a constant T90, i.e., the characteristic time required for a decay of one order of magnitude, or $90 \%$, in the bacterial concentration, irrespective of dilution processes.

In fact, no matter how sophisticated are the coupling of near and far field hydrodynamic and turbulent transport models, if the decay kinetic is not realistically simulated, calculations of bacterial concentrations will be, at least, very questionable, CARVALHO, J.L. et al. (2006).

FEITOSA et al. (2013) present an extensive analysis comparing eight bacterial decay models for computing the fate of plumes of submarine sewage outfalls.

Starting with the work of FEITOSA R.C. (2007), the modeling system $\mathrm{SisBaHi} A \circledast$, can realistically simulate coupled processes in the near and far fields with bacterial decay kinetics varying with water salinity and temperature, and incidence of solar radiation. Details in section 7.5 in ROSMAN P.C.C. (Ed.), (2016).

With the aid of such modeling tools one can perform confident analysis concerning the risk of polluting bathing waters in beaches in the vicinity of outfalls. For design purposes, it is possible to optimize the length of an outfall, for a given a risk factor that the plume might reach the bathing water zone, with improper bacterial concentration.
Considering that one kilometer of outfall has a multimillion dollars cost, such optimization analyses have a very interesting benefit / cost ratio, minimizing uncertainties. Figure 5 illustrates the concept for the case of the ESPN outfall in the coast of Natal, State of Rio Grande do Norte, Brazil.

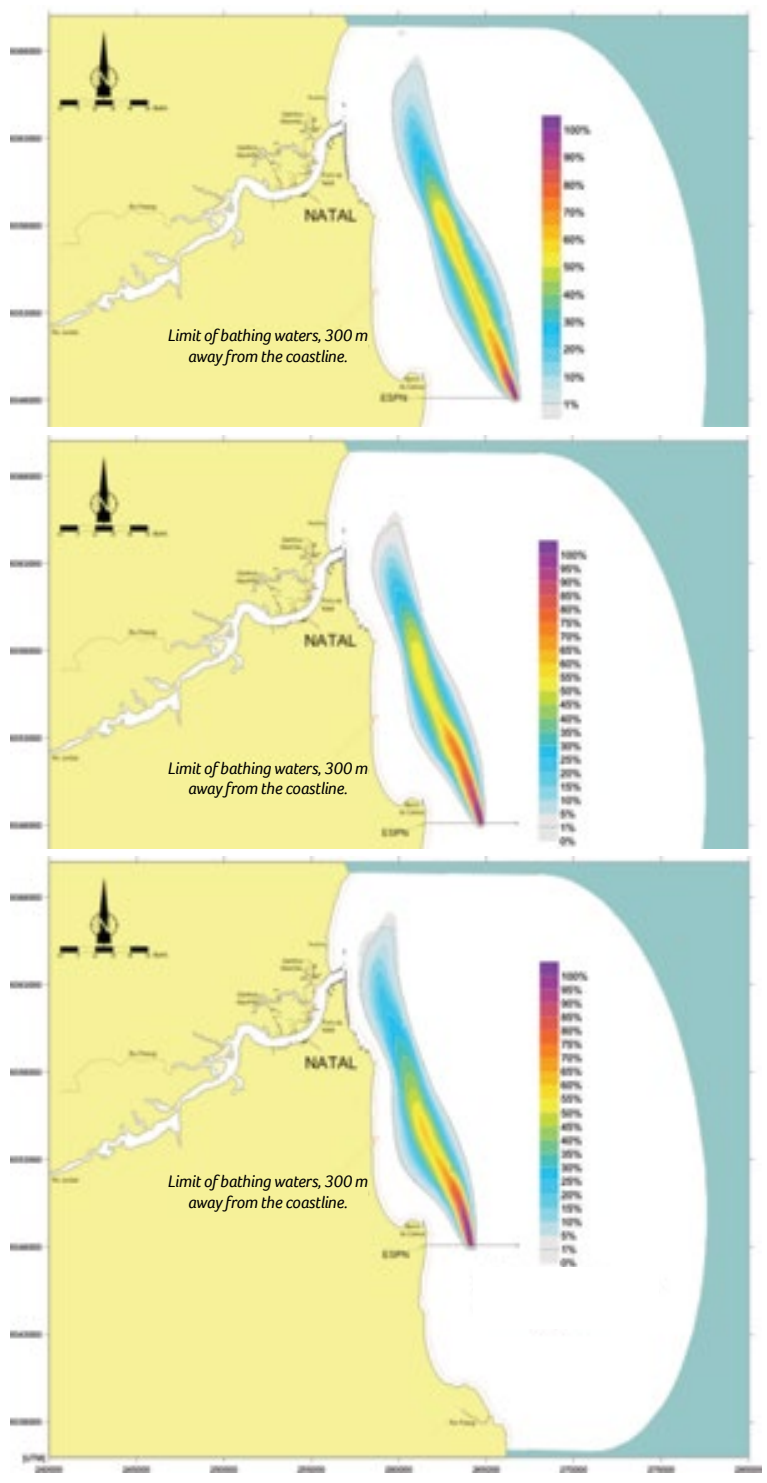

Figure 5: Optimizing outfall length: Isolines of probability of passage of the plume with $\mathrm{FC}>1000$ $\mathrm{mpn} / 100 \mathrm{~mL}$, v. Table 4, for three different lengths of the outfall. ROSMAN P.C.C., SCUDELARI, A.C. (2009). 


\section{REFERENCES}

BLENINGER T., (2006). “Coupled 3D hydrodynamic models for submarine outfalls: environmental hydraulic design and control of multiport diffusers". D.Sc. Thesis, KIT - Karlsruhe Institute of Technology, Germany.

CARVALHO, J. L. B.; FEITOSA, R.C.; ROSMAN, P.C.C.; ROBERTS, P.J.W. (2006). A bacterial decay model for coastal outfall plumes. Journal of Coastal Research, v. III, p. 1524-1528, 2006.

CONAMA 274/2000, November 29th, 2000.

CONAMA 357/2005, March 17th, 2005.

CONAMA 430/2011, March 13th, 2011.

FEITOSA, R.C. \& ROSMAN P.C.C., (2007). (In Portuguese). "Submarine sewage outfalls: Water quality and computational modeling aspects". Vol. 8 of Numerical Methods in Water Resources Brazilian Association of Water Resources (ABRH), www.abrh.org. br/livros/met 8.asp

FEITOSA, R.C., (2007). (In Portuguese) "Coupling of near and far field models with kinetics of variable bacterial decay - Applications for submarine outfalls".D.Sc. Thesis - Coastal and Oceanographic Engineering- PENO - COPPE/UFRJ, Brazil.

FEITOSA, R.C.; ROSMAN P.C.C.; CARVALHO, J.L.B.; CÔRTES, M.B.; WASSERMAN J.C. (2013). "Comparative study of fecal bacterial decay models for the simulation of plumes of submarine sewage outfalls". Water Science \& Technology, 68.3., pp. 622-631.

GRACE, R.A. - Marine Outfall Systems, Prentice-Hall, 1978.

HANSEN, J.A. - Marine Water Disposal, Danish Isotope Center, Report 25/67.
HORITA, C.O., (1997).(In Portuguese) "Studies for applying and validating a lagrangian transport model of contaminants in shallow water bodies". M.Sc. Thesis - Coastal and Oceanographic Engineering- PENO - COPPE/UFRJ, Brazil.

JORDÃO \& PESSÔA, (2014) (In Portuguese), Domestic Sewage Treatment, ABES, 2014.

METCALF \& EDDY, Wastewater Engineering. McGraw Hill, 2014.

ROBERTS, P.J.W., 1979, "Line Plume and Ocean Outfall Dispersion”. Journal of Hydraulics Division, ASCE, 105 (HY4), pp. 313330.

ROSMAN P.C.C. (Ed.), (2016). (In Portuguese) "Technical Reference of SisBaHiA ${ }^{\circledR}$ - Base System for Environmental Hydrodynamics". Referência Técnica at www.sisbahia.coppe.ufrj.br

ROSMAN, P.C.C.; SCUDELARI, A.C., (2009). (In Portuguese) “Analyses for prognostic of the Ponta Negra submarine outfall (ESPN), Natal, RN". Coppetec Report, PENO11827, 04/2009.

SANTOS, L.H., (1995). (In Portuguese) “A particle trajectory model for shallow water bodies.The Icarai outfall case, Guanabara Bay". M.Sc. Thesis - Coastal and Oceanographic EngineeringPENO - COPPE/UFRJ, Brazil.

SURSAN, DES - A Master Plan for Waste Disposal for the City of Rio de Janeiro, Engineering Science, 1964.

ZHANG, X.Y. \& ADAMS, E.E., (1999). "Prediction of near field plume characteristics using far field circulation model, Journal of Hydraulic Engineering, Vol. 125, No. 3. 